Randomized Trial

\title{
The Effectiveness of Fluoroscopic Cervical Interlaminar Epidural Injections in Managing Chronic Cervical Disc Herniation and Radiculitis: Preliminary Results of a Randomized, Double- Blind, Controlled Trial
}

Laxmaiah Manchikanti, MD, Kimberly A. Cash, RT, Vidyasagar Pampati, MSc, Bradley W. Wargo, DO, and Yogesh Malla, MD

From: Pain Management Center of Paducah, Paducah, KY

Dr. Manchikanti is Medical Director of the Pain

Management Center of Paducah, Paducah, KY, and Associate Clinical Professor of Anesthesiology and Perioperative Medicine, University of Louisville, Louisville, KY

Mrs. Cash is a Research Coordinator at the Pain Management Center of Paducah, Paducah, KY Mr. Pampati is a Statistician at the Pain Management Center of

Paducah, Paducah, KY

Dr. Wargo is an Interventional

Pain Physician at the Pain

Management Center of

Paducah, Paducah, KY

Dr. Malla is an Interventional Pain Physician at the Pain Management Center of

Paducah, Paducah, KY

Address correspondence: Laxmaiah Manchikanti, MD 2831 Lone Oak Road

Paducah, Kentucky 42003

E-mail: drlm@thepainmd.com

Disclaimer: There was no external funding in the preparation of this manuscript.

Conflict of interest: None.

Manuscript received: $04 / 22 / 2010$

Revised: 05/08/2010 Accepted for publication: 05/10/2010

Free full manuscript: www.painphysicianjournal.com
Background: Chronic neck pain is a common problem in the adult population with a typical 12month prevalence of $30 \%$ to $50 \%$. Cervical disc herniation and radiculitis is one of the common conditions described responsible for chronic neck and upper extremity pain.

Cervical epidural injections for managing chronic neck pain with disc herniation are one of the commonly performed non-surgical interventions in the United States. However, the literature supporting cervical interlaminar epidural steroids in managing chronic neck pain is scant.

Study Design: A randomized, double-blind, controlled trial.

Setting: A private interventional pain management practice and specialty referral center in the United States.

Objectives: To evaluate the effectiveness of cervical interlaminar epidural injections of local anesthetic with or without steroids in providing effective and long-lasting relief in the management of chronic neck pain and upper extremity pain in patients with disc herniation and radiculitis, and to evaluate the differences between local anesthetic with or without steroids.

Methods: Patients were randomly assigned to one of 2 groups: Group I patients received cervical interlaminar epidural injections of local anesthetic (lidocaine 0.5\%, $5 \mathrm{~mL}$ ); Group II patients received cervical interlaminar epidural injections with $0.5 \%$ lidocaine, $4 \mathrm{~mL}$, mixed with $1 \mathrm{~mL}$ of nonparticulate betamethasone.

Outcomes Assessment: Multiple outcome measures were utilized. They included the Numeric Rating Scale (NRS), the Neck Disability Index (NDI), employment status, and opioid intake. Assessments were done at baseline and 3, 6, and 12 months post-treatment.

Significant pain relief was defined as $50 \%$ or more; significant improvement in disability score was defined as a reduction of $50 \%$ or more.

Results: Significant pain relief ( $\geq 50 \%$ ) was demonstrated in $77 \%$ of patients in both groups. Functional status improvement was demonstrated by a reduction (> 50\%) in the NDI scores in $74 \%$ of Group I and $71 \%$ of Group II at 12 months. The overall average procedures per year were $3.7 \pm 1.1$ in Group I and $4.0 \pm 0.91$ in Group Il; the average total relief per year was $39.45 \pm 11.59$ weeks in Group I and $41.06 \pm$ 11.56 weeks in Group II over the 52 week study period in the patients defined as successful.

The initial therapy was considered to be successful if a patient obtained consistent relief with 2 initial injections lasting at least 4 weeks. All others were considered failures.

Limitations: The study results are limited by the lack of a placebo group and a preliminary report of 70 patients, 35 in each group.

Conclusion: Cervical interlaminar epidural injections with local anesthetic with or without steroids might be effective in $77 \%$ of patients with chronic function-limiting neck pain and upper extremity pain secondary to cervical disc herniation and radiculitis.

Key words: Chronic neck pain, cervical disc herniation, upper extremity pain, cervical epidural injections, epidural steroids, local anesthetics

CLINICAL TRIAL: NCT01071369 
eck pain is common in the adult general population. It is disabling and costly (1-6). Studies of the prevalence of chronic neck pain and its impact on general health showed 14\% of patients reporting Grade II to IV neck pain with a high pain intensity leading to disability $(4,5)$. Cervical disc herniation is considered one of the most common conditions of neck pain, causing radiculitis (7). In a study at the Mayo Clinic, the annual incidence of cervical radiculopathy was determined to be 83 per 100,000 of those between 13 and 91 years old (8). The most commonly involved levels for disc herniation include C6/C7 (45\% to $60 \%$ of cases), C5/C6 (20\% to $25 \%$ ), and levels $\mathrm{C} 4 / \mathrm{C} 5$ and $\mathrm{C} 7 / \mathrm{T} 1$, each representing approximately $10 \%$ of cases (8).

Among the various treatments available for managing cervical disc herniation and radiculitis, epidural steroid injections are one of the most common non-surgical interventions (1,9-15). Cervical epidural injections have been used to treat chronic axial neck and radicular pain from herniated discs, spinal stenosis, post-cervical surgery syndrome, and pain of discogenic origin. Epidural injections in the cervical spine are performed either by interlaminar or transforaminal approaches $(1,14,16)$. However, the evidence for cervical interlaminar epidural injections has been a subject of debate and at best has only moderate success in managing cervical radiculopathy. Benyamin et al (1), in a systematic review of cervical interlaminar epidural injections, determined that the evidence was Level II-1 in managing chronic neck and upper extremity pain. Thus, the epidural injections continue to be controversial, similar to lumbar epidural injections, due to the design of the study (fluoroscopic versus non-fluoroscopic), study size, outcome parameters, duration of follow-up, bias exerted in review, and inappropriate methodology leading to inappropriate conclusions $(1,17-27)$.

Benyamin et al (1) included 3 studies meeting inclusion criteria (28-30); however, none were performed under fluoroscopic visualization. The underlying mechanism of epidurally administered local anesthetic and steroids is not clear. It has been hypothesized that the effects of a neural blockade are dependent on the anti-inflammatory properties of corticosteroids (31-38). However, there is also emerging evidence that local anesthetics may be equally effective as steroids in managing spinal pain accompanied with or without disc herniation, secondary to post laminectomy syndrome, and of facet joint origin as well as in multiple other types of nerve blocks (39-51).
Cervical epidural injections have not been performed utilizing contemporary interventional pain management techniques with fluoroscopy and targeted delivery of medication. Consequently, this study is undertaken to evaluate the role of cervical interlaminar epidural injections in patients with chronic, functionlimiting, neck pain and upper extremity pain secondary to disc herniation using local anesthetic with or without steroids. The study is designed to evaluate 120 patients. This preliminary report includes 70 patients completing a one-year follow-up.

\section{Methods}

The study is being conducted in a private interventional pain management practice and specialty referral center in the United States. The study is being performed based on Consolidated Standards of Reporting Trials (CONSORT) guidelines $(21,22,52,53)$. The study protocol was approved by the Institutional Review Board (IRB) and registered on the U.S. Clinical Trial Registry with an assigned number of NCT01071369.

\section{Participants}

Patients were assigned to one of 2 groups: Group I patients received cervical interlaminar epidural injections of local anesthetic (lidocaine $0.5 \%, 5 \mathrm{~mL}$ ); Group II patients received cervical interlaminar epidural injections with $0.5 \%$ lidocaine, $4 \mathrm{~mL}$, mixed with $1 \mathrm{~mL}$ or 6 $\mathrm{mg}$ of non-particulate betamethasone for a total of 5 $\mathrm{mL}$ of injectate.

\section{Interventions}

All patients were provided with the IRB-approved protocol and informed consent which described in detail all aspects of the study and withdrawal process.

\section{Pre-Enrollment Evaluation}

The pre-enrollment evaluation included demographic data, medical and surgical history with co-existing disease(s), radiologic investigations, physical examination, pain rating scores using the Numeric Rating Scale (NRS), work status, opioid intake, and functional status assessment using the Neck Disability Index (NDI).

\section{Inclusion Criteria}

Inclusion criteria were patients with cervical disc herniation or radiculitis; patients who were 18 years of age; patients with a history of chronic functionlimiting neck and upper extremity pain of at least 6 months duration; and patients who were competent to 
understand the study protocol and provide voluntary, written informed consent and participate in outcome measurements.

Exclusion criteria were previous cervical spine surgery, radiculitis secondary to spinal stenosis without disc herniation, uncontrollable or unstable opioid use, uncontrolled psychiatric disorders, uncontrolled medical illness either acute or chronic, any conditions that could interfere with the interpretation of the outcome assessments, pregnant or lactating women, and patients with a history or potential for adverse reaction(s) to local anesthetics or steroid.

\section{Description of Interventions}

All cervical interlaminar epidural procedures were performed by one physician in an ambulatory surgery setting, in a sterile operating room, under fluoroscopy, with patients in the prone position, under appropriate monitoring with intravenous access and sedation with midazolam and fentanyl. Access to the epidural space was obtained under sterile conditions with loss of resistance techniques under fluoroscopic visualization. The epidural space was entered between $\mathrm{C} 7$ and $\mathrm{T} 1$ to $\mathrm{C5}$ and $\mathrm{C} 6$ with confirmation by injection of non-ionic contrast. Following this, an injection of $5 \mathrm{~mL}$ of lidocaine hydrochloride $0.5 \%$ preservative free, or $4 \mathrm{~mL}$ of lidocaine preservative free mixed with $6 \mathrm{mg}$ of non-particulate betamethasone, was carried out.

Repeat cervical epidural injections were provided based on the response to prior cervical epidural injections evaluated by improvement in physical and functional status. Further, repeat cervical epidural injections were performed only when increased levels of pain were reported with deteriorating relief below $50 \%$.

\section{Additional Interventions}

All patients underwent the treatments as assigned. A patient was unblinded on request or if an emergency situation arose. If a patient required additional cervical epidural injections, these were provided based on the patient's response, either after unblinding or without unblinding. If patients chose not to be unblinded, or were non-responsive, and different treatments other than cervical epidural injections were required, they were considered to be withdrawn from the study, and no subsequent data were collected. However, patients who were non-responsive and continued with conservative management were followed without further epidural injections with medical management, unless they requested unblinding. In addition, all patients who were lost to follow-up were considered withdrawn. If patients were unavailable for follow-up, they were considered as lost-to-follow-up.

\section{Co-Interventions}

Most patients were receiving opioids and nonopioid analgesics, adjuvant analgesics; some were involved in a therapeutic exercise program. If patients were improving significantly and the medical necessity for these drugs was lacking, medications were stopped or dosages were decreased. In addition, some dosages were increased, based on medical necessity. All patients continued previously directed exercise programs, as well as their work. Thus, in this study, there was no specific physical therapy, occupational therapy, bracing, or other interventions offered other than the study intervention.

\section{Objectives}

The study was designed to evaluate the effectiveness of cervical epidural injections with or without steroids in managing chronic neck and upper extremity pain secondary to disc herniation or radiculitis in providing effective and long-lasting pain relief and to evaluate the differences between local anesthetic with or without steroids.

\section{Outcomes}

Outcomes measured included NRS, NDI, work status, and opioid intake in terms of morphine equivalents. Assessments were done at baseline, 3, 6, and 12 months post-treatment.

Significant improvement was defined as at least $50 \%$ pain relief associated with $50 \%$ improvement in NDI. The NDI has been shown to be valid and reliable in patients with mechanical neck pain (54-56).

Opioid intake was evaluated based on the dosage frequency and schedule of the drug, with conversion to morphine equivalents (57).

Patients unemployed or employed on a part-time basis with limited or no employment due to pain were classified as employable. Patients who chose not to work, were retired, or were homemakers (not working, but not due to pain) were not considered in the employment pool.

\section{Sample Size}

The sample size was calculated based on significant pain relief. Considering a 0.05 two-sided significance level, a power of $80 \%$, and an allocation ratio 
of 1:1, 55 patients in each group were estimated (58). Allowing for a $10 \%$ attrition/ non-compliance rate, 60 subjects were required.

Previous studies of interventional techniques identified 50 to 60 patients as appropriate $(45-49,51,59)$.

\section{Randomization}

From a total of 120 patients, 60 patients were randomly assigned into each group.

\section{Sequence Generation}

Randomization was performed by computergenerated random allocations sequence by simple randomization.

\section{Allocation Concealment}

The operating room nurse assisting with the procedure randomized the patients and prepared the drugs appropriately.

\section{Implementation}

Participants were invited to enroll in the study if they met inclusion criteria. One of the 3 nurses assigned as coordinators of the study enrolled the participants and assigned participants to their respective groups.

\section{Blinding (Masking)}

Participants and those administering the interventions were blinded to group assignment. Both solutions were clear; it was impossible to identify if the steroid had been added or not. Further, blinding was ensured by mixing the patients with other patients receiving routine treatment and by not informing the physician performing the procedures which patients were in the study. All one-year follow-up patients were selected by a statistician not involved in patient care. The unblinding results were not disclosed to either the treating physician or other participants or patients. Thus, the nature of blinding was not interrupted.

\section{Statistical Methods}

Statistical analysis included the chi-squared statistic, Fisher's exact test, t-test, and paired t-test. Results were considered statistically significant if the $P$ value was less than 0.05 .

Chi-squared statistic was used to test the differences in proportions. Fisher's exact test was used wherever the expected value was less than 5; a paired t-test was used to compare the pre- and post-treatment results of average pain scores and NDI measurements at baseline versus 3, 6, and 12 months. For comparison of mean scores between groups, t-test was performed.

\section{Intent-to-Treat-Analysis}

An intent-to-treat-analysis was performed. Either the last follow-up data or initial data were utilized in patients who dropped out of the study and no other data were available. Sensitivity analysis was performed utilizing best case, worse case, and last follow-up data.

\section{Results}

\section{Participant Flow}

Figure 1 illustrates the participant flow.

\section{Recruitment}

The recruitment period lasted from August 2007 to April 2009.

\section{Baseline Data}

Baseline demographic and clinical characteristics of each group are illustrated in Table 1. There were no significant differences noted. Of the 70 patients included in the study, disc herniation was noted at C5/6 in $9 \%$ of the patients, $C 6 / 7$ in $64 \%$ of the patients, and at C7/T1 in $27 \%$ of the patients.

\section{Analysis of Data}

\section{Numbers Analyzed}

A schematic illustration of patient flow is provided in Fig. 1. The study period for one-year follow-up lasted from August 2008 to April 2010. Seventy patients completed the one-year follow-up; 35 patients in each group. The data were available in the majority of the included patients. Intent-to-treat analysis was performed due to non-available data on 2 occasions on one patient in Group I, and on 3 occasions on 2 patients in Group II. Based on the number of treatments provided, lack of follow-up was found in 2 of 105 occasions in Group I (2\%) or 1 of 35 patients (3\%); 3 of 105 occasions (3\%) in Group II with 2 of 35 patients (6\%) at least one time.

\section{Sensitivity Analysis}

A sensitivity analysis with changes in the numeric pain scores was performed utilizing the last followup score, best case scenario, and worst case scenario. There were no significant differences; therefore, the intention-to-treat analysis with last follow-up visit was used. 


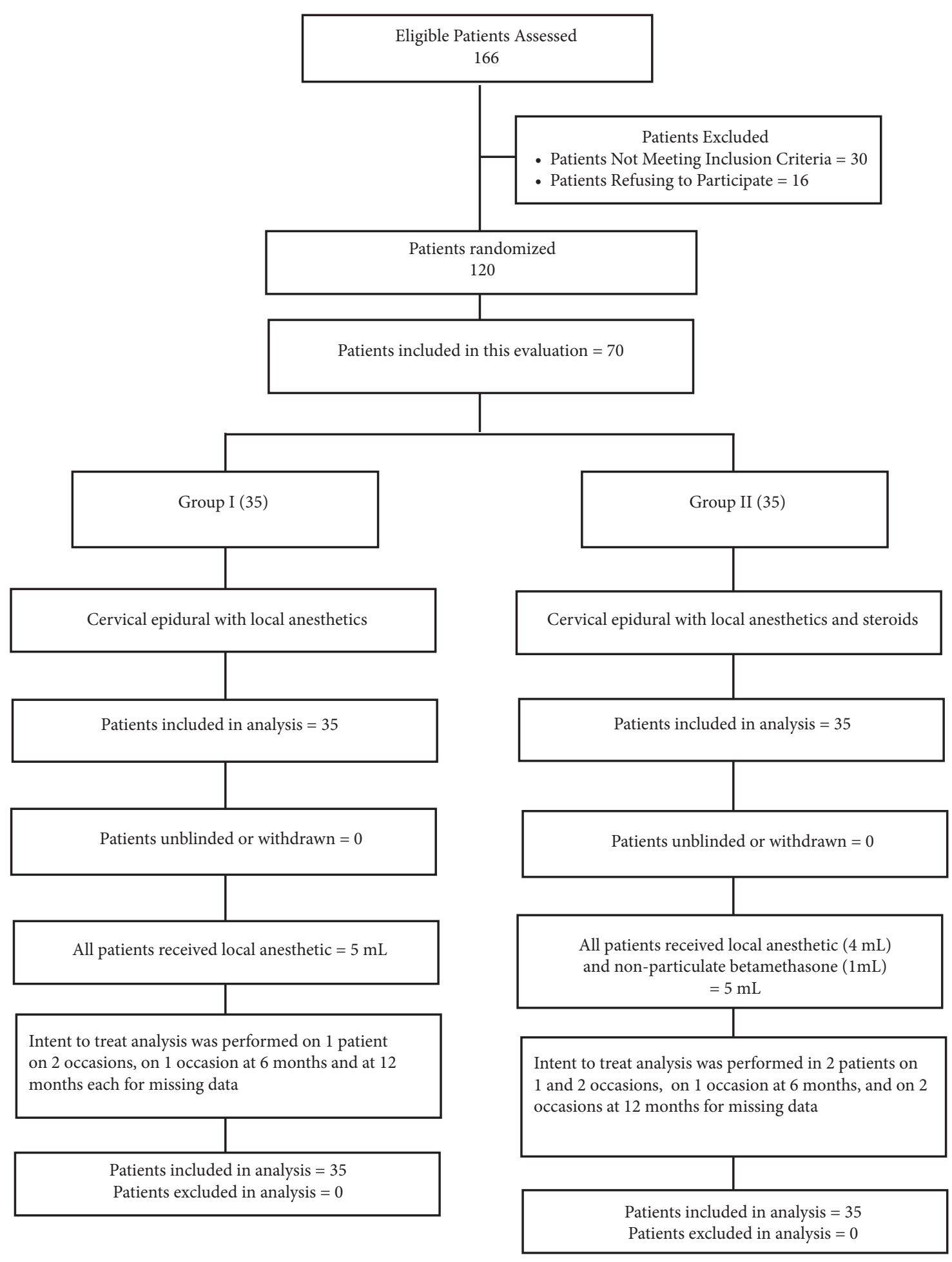

Fig. 1. Schematic presentation of patient flow at 1-year follow-up. 
Table 1. Baseline demographic characteristics.

\begin{tabular}{|c|c|c|c|c|}
\hline & & $\begin{array}{c}\text { Group } 1 \\
(35)\end{array}$ & $\begin{array}{c}\text { Group II } \\
(\mathbf{3 5})\end{array}$ & $P$ value \\
\hline \multirow{2}{*}{ Gender } & Male & $31 \%(11)$ & $40 \%(14)$ & \multirow{2}{*}{0.454} \\
\hline & Female & $69 \%(24)$ & $60 \%(21)$ & \\
\hline Age & Mean \pm SD & $46.7 \pm 11.4$ & $45.5 \pm 9.8$ & 0.646 \\
\hline Weight & Mean \pm SD & $186.5 \pm 46.3$ & $168.2 \pm 42.2$ & 0.088 \\
\hline Height & Mean \pm SD & $66.0 \pm 4.0$ & $66.5 \pm 4.1$ & 0.598 \\
\hline Duration of Pain (months) & Mean \pm SD & $104.4 \pm 99.1$ & $83.1 \pm 82.9$ & 0.598 \\
\hline \multirow{2}{*}{ Onset of Pain } & Gradual & $54 \%(19)$ & $47 \%(16)$ & \multirow{2}{*}{0.548} \\
\hline & Injury & $46 \%(16)$ & $53 \%(19)$ & \\
\hline \multirow{5}{*}{$\begin{array}{l}\text { Disc Herniation Levels } \\
\text { (at multiple levels) }\end{array}$} & $\mathrm{C} 3 / 4$ & $20 \%(7)$ & $14 \%(5)$ & \multirow{5}{*}{$\mathrm{N} / \mathrm{A}$} \\
\hline & $\mathrm{C} 4 / 5$ & $37 \%(13)$ & $29 \%(10)$ & \\
\hline & $\mathrm{C} 5 / 6$ & $63 \%(22)$ & $63 \%(22)$ & \\
\hline & C6/7 & $49 \%(17)$ & $54 \%(19)$ & \\
\hline & $\mathrm{C} 7 / \mathrm{T} 1$ & $11 \%(4)$ & $6 \%(2)$ & \\
\hline Numeric Rating Score & Mean \pm SD & $7.8 \pm 0.92$ & $7.6 \pm 0.91$ & 0.302 \\
\hline Neck Disability Index & Mean \pm SD & $29.8 \pm 5.6$ & $28.7 \pm 8.4$ & 0.514 \\
\hline
\end{tabular}

Table 2. Pain relief characteristics.

\begin{tabular}{|l|c|c|c|}
\hline \multirow{2}{*}{$\begin{array}{l}\text { Numeric } \\
\text { Rating Score }\end{array}$} & Group I (35) & Group II (35) & \multirow{2}{*}{ P value } \\
\cline { 2 - 3 } & Mean \pm SD & Mean \pm SD & \\
\hline Baseline & $7.8 \pm 0.92$ & $7.6 \pm 0.91$ & 0.302 \\
\hline 3 months & $3.2^{*} \pm 1.06$ & $3.4^{*} \pm 1.12$ & 0.445 \\
\hline 6 months & $3.2^{*} \pm 1.13$ & $3.4^{*} \pm 1.01$ & 0.320 \\
\hline 12 months & $3.3^{*} \pm 1.19$ & $3.5^{*} \pm 1.20$ & 0.485 \\
\hline
\end{tabular}

${ }^{\star}$ indicates significant difference with baseline values $(P<0.001)$

\section{Outcomes}

\section{Pain Relief}

Table 2 illustrates the NRS scores. Pain scores changed significantly from baseline at 3, 6, and 12 months in both groups There were no significant differences between the groups at the follow-up periods.

The proportion of patients with significant pain relief of $50 \%$ or greater is illustrated in Fig. 2 showing $77 \%$ in both Groups I and II at 12 months. There were no significant differences between the groups at the 3-month to 6-month to 12 -month periods.

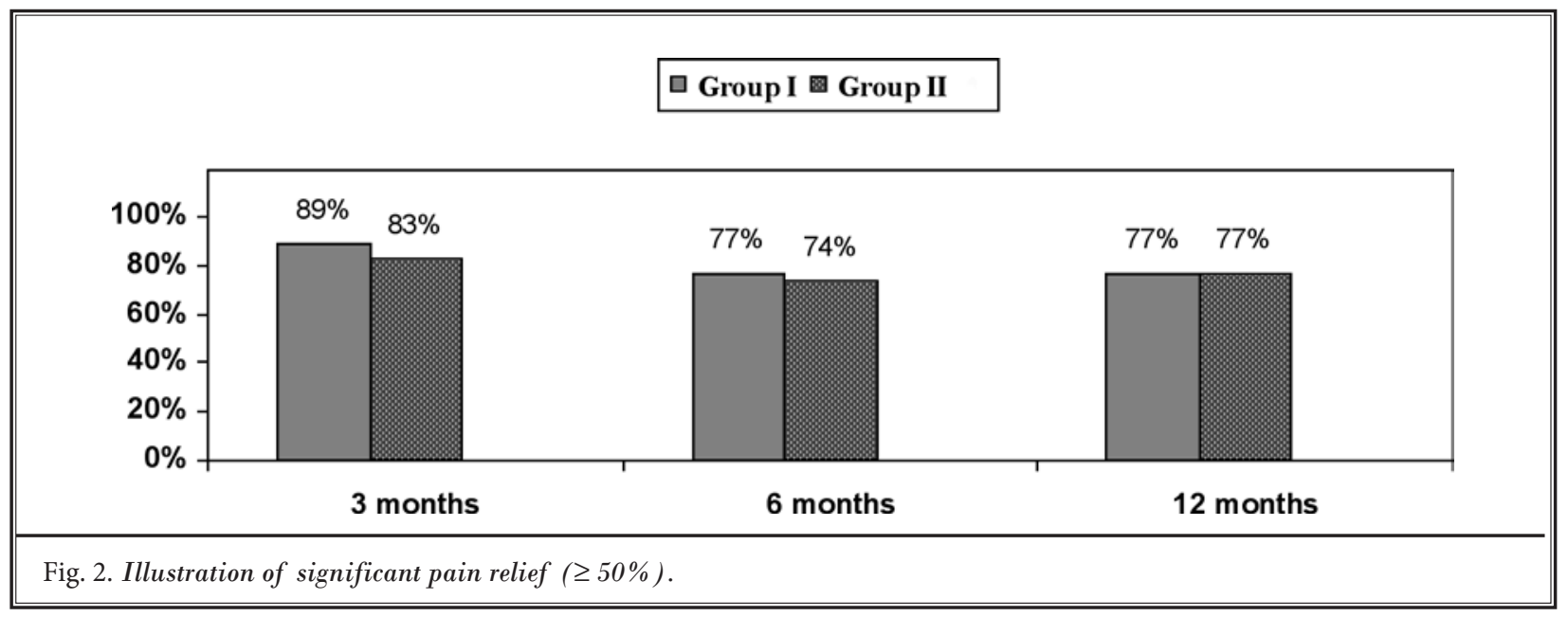




\section{Functional Assessment}

Functional assessment results assessed by the NDI are illustrated in Table 3. Significant improvement was seen in the functional status in both groups from baseline to one year. Reduction of Neck Disability Index Scores of at least $50 \%$ was seen in $74 \%$ (Group I) and $71 \%$ (Group II) at 12-months as shown in Fig. 3. There were no significant differences between the groups during follow-up periods.

\section{Employment Characteristics}

Table 4 demonstrates employment characteristics in both groups.
Table 3. Functional assessment evaluated by Neck Disability Index.

\begin{tabular}{||l|l|l|l||}
\hline Neck Disability Index & \multicolumn{1}{|c|}{$\begin{array}{c}\text { Group I } \\
(\mathbf{3 5 )}\end{array}$} & $\begin{array}{c}\text { Group II } \\
\mathbf{( 3 5 )}\end{array}$ & P value \\
\hline Mean \pm SD & Mean \pm SD & \\
\hline Baseline & $29.8 \pm 5.6$ & $28.7 \pm 8.4$ & 0.514 \\
\hline 3 months & $14.6^{\star} \pm 5.67$ & $14.1^{\star} \pm 5.60$ & 0.735 \\
\hline 6 months & $13.1^{*} \pm 5.46$ & $13.9^{*} \pm 5.71$ & 0.580 \\
\hline 12 months & $13.5^{*} \pm 5.33$ & $13.8^{*} \pm 5.46$ & 0.825 \\
\hline
\end{tabular}

${ }^{*}$ indicates significant difference with baseline values $(P<0.001)$

\section{口 Group I 圆 Group II}

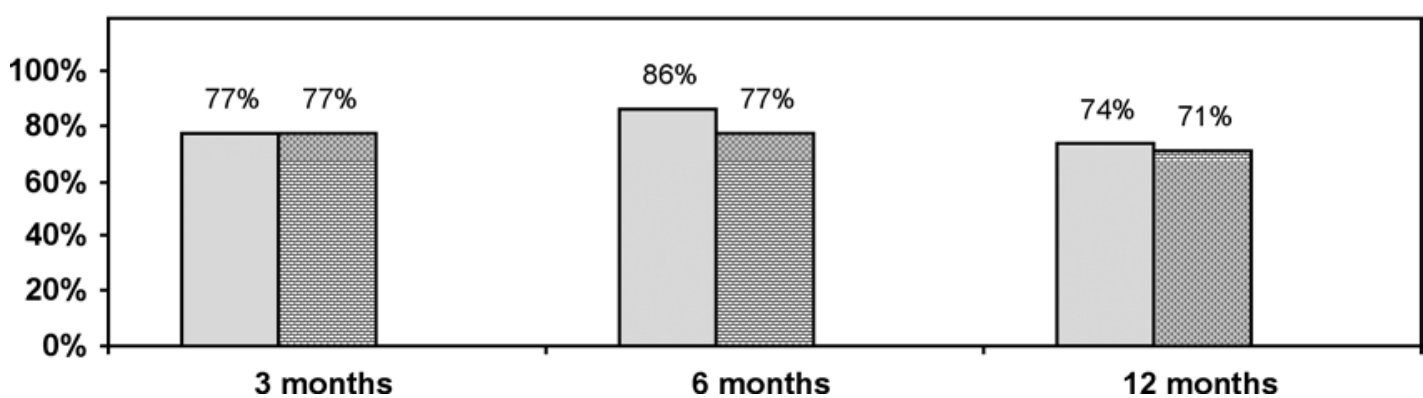

Fig. 3. Illustration of reduction (at least $50 \%$ ) in Neck Disability Index from baseline.

Table 4. Employment characteristics

\begin{tabular}{|c|c|c|c|c|}
\hline \multirow{2}{*}{ Employment status } & \multicolumn{2}{|c|}{ Group I } & \multicolumn{2}{|c|}{ Group II } \\
\hline & Baseline & 12 months & Baseline & 12 months \\
\hline Employed part-time & 2 & 0 & 3 & 3 \\
\hline Employed full-time & 4 & 7 & 7 & 6 \\
\hline Unemployed (due to pain) & 3 & 2 & 2 & 3 \\
\hline Not working & 2 & 2 & 0 & 0 \\
\hline Eligible for employment & 11 & 11 & 12 & 12 \\
\hline Total Employed & 6 & 7 & 10 & 9 \\
\hline Housewife & 22 & 22 & 21 & 21 \\
\hline Disabled & 2 & 2 & 1 & 1 \\
\hline Retired & 0 & 0 & 1 & 1 \\
\hline Total Number of Patients & 35 & 35 & 35 & 35 \\
\hline
\end{tabular}




\section{Opioid Intake}

Table 5 illustrates opioid intake between the groups at baseline, at 3 months, at 6 months, and at 12 months. No significant increase in opioid intake was shown. However, opioid intake significantly decreased from the baseline in both groups at 3, 6, and 12 months.

\section{Therapeutic Procedural Characteristics}

Therapeutic procedural characteristics are illustrated in Table 6. Epidural entry was perfomed between $\mathrm{C7}$ and $\mathrm{T} 1$ in $31 \%$ of patients, between $\mathrm{C} 6$ and $\mathrm{C} 7$ in $60 \%$ of patients, and between $\mathrm{C} 5$ and $\mathrm{C} 6$ in $9 \%$ of patients.

Average relief per year showed no significant differences: $37.86 \pm 13.19$ weeks in Group I and $37.66 \pm 15.36$ weeks in Group II. The total number of injections per year was $3.7 \pm 1.09$ in Group I and $3.7 \pm 1.22$ in Group II. However, when patients were separated into successful and failed groups, the total number of injections per year was $3.7 \pm 1.1$ in Group I and $4.0 \pm 0.91$ in Group II in the successful group, and $4.0 \pm 1.41$ for Group I and $2.0 \pm$ 2.0 for Group II in the failed group. Total relief of 39.45 \pm 41.06 weeks was obtained in the successful group in Group I; in Group II it was $41.06 \pm 11.56$. In contrast, the relief was $11.5 \pm 12.02$ in Group I and $11.25 \pm 17.04$ weeks in Group II for the failed groups.

The initial therapy was considered to be successful if a patient obtained consistent relief with 2 initial injections lasting at least 4 weeks. All others were considered failures.

Table 5. Opioid Intake (Morphine Equivalence mg)

\begin{tabular}{|l|c|c|c||}
\hline \hline \multirow{2}{*}{$\begin{array}{c}\text { Opioid intake } \\
\text { (Morphine Equivalence mg) }\end{array}$} & Group I (35) & Group II (35) & \multirow{2}{*}{$\boldsymbol{P}$ value } \\
\cline { 2 - 4 } & Mean \pm SD & Mean \pm SD & 0.602 \\
\hline Baseline & $61.9 \pm 54.1$ & $54.5 \pm 63.2$ & 0.484 \\
\hline 3 months & $50.5 \# \pm 47.9$ & $42.8 \# \pm 43.9$ & 0.563 \\
\hline 6 months & $48.5 \# \pm 47.3$ & $42.1 \# \pm 44.4$ & 0.531 \\
\hline 12 months & $48.5 \# \pm 47.3$ & $41.6 \# \pm 44.9$ & \\
\hline
\end{tabular}

\# indicates significant difference with baseline values $(P<0.05)$

Table 6. Therapeutic procedural characteristics with procedural frequency, average relief per procedure, and average total relief in weeks over a period of one-year.

\begin{tabular}{|c|c|c|c|c|c|c|}
\hline & \multicolumn{2}{|c|}{ Successful subjects } & \multicolumn{2}{|c|}{ Failed subjects } & \multicolumn{2}{|c|}{ Combined } \\
\hline & $\begin{array}{c}\text { Group I } \\
(\mathbf{3 3})\end{array}$ & $\begin{array}{c}\text { Group II } \\
\text { (31) }\end{array}$ & $\begin{array}{l}\text { Group I } \\
\text { (2) }\end{array}$ & $\begin{array}{l}\text { Group II } \\
\text { (4) }\end{array}$ & $\begin{array}{c}\text { Group I } \\
\text { (35) }\end{array}$ & $\begin{array}{c}\text { Group II } \\
(\mathbf{3 5})\end{array}$ \\
\hline 1st procedure relief & $\begin{array}{c}8.67 \pm 9.36 \\
(33)\end{array}$ & $\begin{array}{c}6.15 \pm 4.32 \\
(31)\end{array}$ & $\begin{array}{c}1.75 \pm 1.06 \\
\text { (2) }\end{array}$ & $\begin{array}{c}3.04 \pm 4.21 \\
\quad(4)\end{array}$ & $\begin{array}{c}8.27 \pm 9.23 \\
(35)\end{array}$ & $\begin{array}{c}5.80 \pm 4.37 \\
(35)\end{array}$ \\
\hline 2nd procedure relief & $\begin{array}{l}10.88 \pm 4.98 \\
\quad(32)\end{array}$ & $\begin{array}{c}11.35 \pm 6.50 \\
(31)\end{array}$ & $\begin{array}{l}1.0 \pm 1.41 \\
\text { (2) }\end{array}$ & $\begin{array}{l}2.00 \\
(1)\end{array}$ & $\begin{array}{c}10.29 \pm 5.38 \\
\quad(34)\end{array}$ & $\begin{array}{c}11.06 \pm 6.61 \\
\quad(32)\end{array}$ \\
\hline 3rd procedure relief & $\begin{array}{c}12.36 \pm 5.49 \\
(28)\end{array}$ & $\begin{array}{c}12.61 \pm 5.46 \\
(28)\end{array}$ & $\begin{array}{c}2.64 \pm 3.34 \\
(2)\end{array}$ & $\begin{array}{l}9.00 \\
(1)\end{array}$ & $\begin{array}{c}11.71 \pm 5.87 \\
(23)\end{array}$ & $\begin{array}{c}12.48 \pm 5.40 \\
(29)\end{array}$ \\
\hline 4 th procedure relief & $\begin{array}{l}12.18 \pm 2.20 \\
(22)\end{array}$ & $\begin{array}{c}11.75 \pm 2.38 \\
(24)\end{array}$ & 13.00 & $\begin{array}{c}9.00 \\
(1)\end{array}$ & $\begin{array}{l}12.22 \pm 2.15 \\
(23)\end{array}$ & $\begin{array}{l}11.64 \pm 2.40 \\
(25)\end{array}$ \\
\hline 5 th procedure relief & $\begin{array}{l}8.57 \pm 5.13 \\
(7)\end{array}$ & $\begin{array}{l}11.44 \pm 2.60 \\
(9)\end{array}$ & 0.00 & $\begin{array}{l}13.00 \\
(1)\end{array}$ & $\begin{array}{c}7.50 \pm 5.63 \\
(8)\end{array}$ & $\begin{array}{l}11.60 \pm 2.50 \\
(10)\end{array}$ \\
\hline Number of procedures per year & $\begin{array}{c}3.7 \pm 1.1 \\
(33)\end{array}$ & $\begin{array}{l}4.0 \pm 0.91 \\
(31)\end{array}$ & $\begin{array}{l}4.0 \pm 1.41 \\
\text { (2) }\end{array}$ & $\begin{array}{c}2.0 \pm 2.0 \\
(4)\end{array}$ & $\begin{array}{c}3.7 \pm 1.09 \\
(35)\end{array}$ & $\begin{array}{c}3.7 \pm 1.22 \\
(35)\end{array}$ \\
\hline Average relief per procedure & $\begin{array}{c}11.88 \pm 8.25 \\
(33)\end{array}$ & $\begin{array}{c}10.56 \pm 3.42 \\
(31)\end{array}$ & $\begin{array}{l}2.50 \pm 2.12 \\
\text { (2) }\end{array}$ & $\begin{array}{c}4.05 \pm 4.73 \\
(4)\end{array}$ & $\begin{array}{c}11.34 \pm 8.31 \\
(35)\end{array}$ & $\begin{array}{c}9.82 \pm 4.09 \\
(35)\end{array}$ \\
\hline Total relief per year (weeks) & $\begin{array}{c}39.45 \pm 11.59 \\
(33)\end{array}$ & $\begin{array}{c}41.06 \pm 11.56 \\
(31)\end{array}$ & $\begin{array}{c}11.5 \pm 12.02 \\
\text { (2) }\end{array}$ & $\begin{array}{c}11.25 \pm 17.04 \\
\text { (4) }\end{array}$ & $\begin{array}{c}37.86 \pm 13.19 \\
(35)\end{array}$ & $\begin{array}{c}37.66 \pm 15.36 \\
(35)\end{array}$ \\
\hline
\end{tabular}


Table 7. Characteristics of changes in weight.

\begin{tabular}{|c|c|c|c|}
\hline \multirow{2}{*}{ Weight (lbs) } & Group I (35) & Group II (35) & \multirow{2}{*}{$\begin{array}{c}P \\
\text { value }\end{array}$} \\
\hline & Mean \pm SD & Mean \pm SD & \\
\hline Weight at beginning & $186.5 \pm 46.26$ & $168.2 \pm 42.17$ & 0.088 \\
\hline Weight at one year & $185.5 \pm 58.7$ & $167.8 \pm 43.19$ & 0.108 \\
\hline Change & $-1.0 \pm 9.3$ & $-0.4 \pm 10.78$ & 0.804 \\
\hline Lost weight & $37 \%(13)$ & $49 \%(17)$ & \multirow{3}{*}{0.532} \\
\hline No change & $23 \%(8)$ & $14 \%(5)$ & \\
\hline Gained weight & $40 \%(14)$ & $37 \%(13)$ & \\
\hline
\end{tabular}

\section{Changes in Weight}

There were no differences in change (gain or loss) in body weight from baseline in both groups (Table 7).

\section{Adverse Events}

Of the 262 cervical epidural procedures performed, there were 3 subarachnoid punctures. In all cases of subarachnoid entry, reentry was carried out at a different level and the procedure was completed. At the same time, all the patients were given 1,000 mg of caffeine infusion. None of them developed post lumbar puncture headaches.

Nerve root irritation was observed in 3 patients without any long-term sequelae. All patients experiencing nerve root irritation, even though transient, were given $8 \mathrm{mg}$ of Decadron intravenously.

\section{Discussion}

This preliminary report of the one-year follow-up of a randomized trial of 70 patients demonstrates significant pain relief ( $\geq 50 \%$ ) in $77 \%$ of patients in both groups as well as significant improvement in functional status (50\% or greater reduction in NDI scores) in $74 \%$ to $71 \%$ of patients. No significant differences are noted whether or not the injectates contained steroids. The overall average procedures per year was $3.7 \pm 1.09$ in Group I and $3.7 \pm 1.22$ in Group II, with an average total relief per year of $37.86 \pm 13.19$ weeks for Group I and $37.66 \pm 15.36$ weeks for Group II, for the 52 week period. Opioid intake was significantly reduced in both groups, along with pain relief and improvement in functional status.

Despite significant use of epidural injections in the cervical spine, there have been only 2 systematic reviews $(1,60)$, and a Cochrane review of medicinal and injection therapies for mechanical neck disorders (61). Of the randomized evaluations included in the evidence synthesis (28-30), Benyamin et al (1) concluded that all 3 studies showed positive results for short-term relief, whereas 2 were positive for long-term relief; the results of long-term relief were not available for one study (30), defining short-term relief as 6 months, and long-term relief as greater than 6 months. As illustrated in the present study, cervical interlaminar epidural injections of local anesthetic with or without steroids do not provide long-term relief, even though long-term relief can be achieved by appropriate patient evaluation and judicious use of repeat injection therapy. The study illustrates an average relief of 12.36 to 12.61 weeks in the therapeutic phase after 2 initial injections. These results are similar to patients with low back pain treated with caudal epidural injections with or without steroids with or without lumbar disc herniation utilizing the same methodology.

In addition, previous observational studies included homogeneous population, which also included patients with discogenic pain; however, there have not been any randomized trials or observational studies incorporating only discogenic pain after exclusion of cervical facet joint pain. Thus, the results of this trial reinforce previous findings (28-30) of the effectiveness of cervical interlaminar epidural injections with longterm follow-up.

Further, this study also provides insight into successful or failed groups based on the first 2 procedures. The patients in the successful group who had good pain relief with the first and second procedures showed average relief from 39.45 to 41.06 weeks out of 52 weeks. The average number of procedures per year was 3.7. In contrast, in the failed group, the average relief per procedure was 2.5 to 4.05 weeks, with overall 11.5 to 11.25 weeks of relief in one year.

One of the advantages of this evaluation is its generalizability to interventional pain management settings. Further, this is the first study performed under fluoroscopic visualization in the United States, which is considered to be a practical clinical trial, providing more generalizability than a placebo controlled trial. Consequently, the results of this study can be applied to individual patients or groups that differ from those controlled in the placebo trials. Pragmatic or practical clinical trials (with an active control) measuring effectiveness are considered more appropriate than explanatory trials measuring efficacy (20-24,62-67). Pragmatic trials are best designed to provide the results of treatment benefits produced in routine clinical practice, in contrast to explanatory trials (placebo control) that measure efficacy. Utilizing an active con- 
trol design, as in this study, the evidence is based on head-to-head comparisons of clinically relevant alternatives used in routine clinical practice, which include local anesthetic with or without steroids. In contrast, a placebo control trial measures absolute effect size and shows the existence of effect. The present design with active control shows not only the existence of effect, but also compares 2 commonly used therapies (67). This study is also different from other studies since we used repeat cervical interlaminar epidural injections based on the requirement that there be an increase in pain and deterioration in functional status, rather than routinely providing 3 injections or being limited to 3 procedures or limiting them even to only one or 2 procedures. Further, this study also has taken into consideration that the initial 2 procedures do not last for long periods of time. If the initial relief did not last more than one to 3 weeks, then the procedures did not provide long-term relief in patients as observed in the failed subjects.

The study may be criticized or considered as deficient due to the lack of a placebo group and preliminary analysis. Conducting clinical trials with a placebo group is extremely difficult in the United States with interventional techniques. External validity, also known as applicability, is the extent to which the results of the study can be generalized to other circumstances and the general population, and is best provided with pragmatic or active control trials such as this one. The issue of a lack of a placebo group is addressed in pragmatic trials with a treatment response that accounts for the total difference between 2 treatments, as well as associated placebo effects, thus providing the internal validity. This preliminary report might resolve to some extent the issue of local anesthetics with or without steroids in managing chronic function-limiting neck pain and upper extremity pain with disc herniation or radiculitis. These results describe a pattern of practice in the United States in an interventional pain management setting. Thus, the results may not be applicable in the general population unless the same methodology is utilized under fluoroscopy. In addition, the generalizability of the findings of any study might only be feasible if studies are conducted with larger populations in multiple settings.

Placebo-controlled neural blockade is not realistic even though it has been misinterpreted $(68,69)$. Some have mistakenly reported that any local anesthetic injection which yields similar results as steroids is considered a placebo. However, these interpretations are inaccurate. Further, the difference between injections of sodium chloride solution and dextrose have been shown (70). The experimental and clinical findings from investigation of the electrophysiological effects of $0.9 \%$ sodium chloride and dextrose $5 \%$ in water solution have added new knowledge and controversy to multiple aspects of neural stimulation used in regional anesthesia. The potential inaccuracy created by $0.9 \%$ sodium chloride solution versus $5 \%$ dextrose has been described $(70,71)$.

The evidence also has shown differing effects of sodium chloride solution when injected into either the disc, the facet joint, or paraspinal muscles $(72,73)$. Indahl et al $(72,73)$ studied the electromyographic response of the porcine multifidus musculature after nerve stimulation (73) and interaction between the porcine lumbar intervertebral disc, zygapophysial joints, and paraspinal muscles (72). They showed that stimulation of the disc and the facet joint capsule produced contractions in the multifidus fascicles (73). They also demonstrated the introduction of lidocaine into the facet joint resulted in a significantly reduced electromyographic response with the most drastic reduction seen when stimulating the facet joint capsule. Surprisingly, they (72) also showed that the introduction of physiologic saline into the zygapophysial joint reduced the stimulation pathway from the intervertebral disc to the paraspinal musculature. Consequently, they hypothesized that the paraspinal muscle activation caused by nerve stimulation in the annulus fibrosus of a lumbar intervertebral disc could be altered by a saline injection into the zygapophysial joint.

While the mechanism of action of steroids and local anesthetic has been described $(30-43,74-80)$, there is emerging evidence that local anesthetics may be equally as effective as steroids in managing low back and neck pain without disc herniation and also pain of facet joint origin (44-51). It has been reported that multiple pathophysiologic mechanisms involved in chronic pain, including noxious peripheral stimulation, excess nociception resulting in the sensitization of the pain pathways at several neuronal levels, and excess release of neurotransmitters causing complex central responses including hyperalgesia or wind-up (30), result in an increase in nociceptive sensitization of the nervous system $(80,81)$ and phenotype changes which are also considered as part of the neuronal plasticity (80-82). Thus, there is evidence for the long-term effect of either local anesthetics or steroids in managing radicular pain. Corticosteroid anti-inflammatory 
properties have been associated with the inhibition of prostaglandin synthesis and decreases in regional levels or inflammatory mediators such as interleukin1 , tumor necrosis factor, and phospholipase A2 (3043,83-90). The results of this preliminary report show no significant improvement with corticosteroids in managing chronic neck pain with or without upper extremity pain. In addition, corticosteroids are also known to possess direct neurotoxic effects on peripheral nerve tissue unlike local anesthetics $(74,91-93)$.

In summary, the evidence in this preliminary evaluation of a randomized, controlled, double-blind trial demonstrates that cervical interlaminar epidural injections in patients with disc herniation and radiculitis supports that patients may be treated with cervical interlaminar epidural injections with or without steroids.

\section{Conclusion}

The assessment of preliminary results of this randomized, controlled, double-blind trial of cervical interlaminar epidural injections in chronic function-limiting neck pain and upper extremity pain with disc herniation and radiculitis demonstrated significant pain relief in $77 \%$ of patients with improvement in functional status, requiring 3.7 procedures per year and providing almost 38 weeks of relief during a 52 -week period in appropriately selected patients.

\section{Acknowledgements}

The authors wish to thank Sekar Edem for assistance in search of literature, Tom Prigge for manuscript review, and Tonie M. Hatton and Diane E. Neihoff, transcriptionists, for their assistance in preparation of this manuscript. We would like to thank the editorial board of Pain Physician for review and criticism in improving the manuscript.

\section{References}

1. Benyamin RM, Singh V, Parr AT, Conn A, Diwan S, Abdi S. Systematic review of the effectiveness of cervical epidurals in the management of chronic neck pain. Pain Physician 2009; 12:137-157.

2. Manchikanti L. Singh V, Datta S, Cohen SP, Hirsch JA. Comprehensive review of epidemiology, scope, and impact of spinal pain. Pain Physician 2009; 12: E35-E70.

3. Hogg-Johnson S, van der Velde G, Carroll LJ, Holm LW, Cassidy JD, Guzman J, Côté P, Haldeman S, Ammendolia C, Carragee E, Hurwitz E, Nordin M, Peloso P, Bone and Joint Decade 2000-2010 Task Force on Neck Pain and Its Associated Disorders. The burden and determinants of neck pain in the general population: Results of the Bone and Joint Decade 2000-2010 Task Force on Neck Pain and Its Associated Disorders. Spine (Phila Pa 1976) 2008; 33: S39-S51.

4. Côté P, Cassidy JD, Carroll L. The Saskatchewan Health and Back Pain Survey. The prevalence of neck pain and related disability in Saskatchewan adults. Spine (Phila Pa 1976) 1998; 23:1689-1698.
5. Côté P, Cassidy JD, Carroll LJ, Kristman $\mathrm{V}$. The annual incidence and course of neck pain in the general population: $A$ population-based cohort study. Pain 2004; 112:267-273.

6. Côté $P$, Kristman V, Vidmar $M$, Van Eerd D, Hogg-Johnson S, Beaton D, Smith PM. The prevalence and incidence of work absenteeism involving neck pain: A cohort of Ontario lost-time claimants. Spine (Phila Pa 1976) 2008; 33:S192S198.

7. Carette S, Fehlings MG. Clinical practice. Cervical radiculopathy. $N$ Engl J Med 2005; 353:392-399.

8. Radhakrishnan K, Litchy WJ, O’Fallon WM, Kurland LT. Epidemiology of cervical radiculopathy. A population-based study from Rochester, Minnesota, 1976 through 1990. Brain 1994; 117:325-335.

9. Van Zundert J, Harney D, Joosten EA, Durieux ME, Patijn J, Prins MH, Van Kleef $M$. The role of the dorsal root ganglion in cervical radicular pain: Diagnosis, pathophysiology, and rationale for treatment. Reg Anesth Pain Med 2006; 31:152-167.

10. Manchikanti L. Medicare in interventional pain management: A critical anal- ysis. Pain Physician 2008; 11:13-42.

11. Manchikanti L, Pampati V, Boswell MV, Smith HS, Hirsch JA. Analysis of the growth of epidural injections and costs in the Medicare population: A comparative evaluation of 1997, 2002, and 2006 data. Pain Physician 2010; 13:199-212.

12. Manchikanti L, Singh V, Pampati V, Smith HS, Hirsch JA. Analysis of growth of interventional techniques in managing chronic pain in Medicare population: A 10-year evaluation from 1997 to 2006. Pain Physician 2009; 12:9-34.

13. Manchikanti L, Singh V, Derby R, Schultz DM, Benyamin RM, Prager JP, Hirsch JA. Reassessment of evidence synthesis of occupational medicine practice guidelines for interventional pain management. Pain Physician 2008; 11:393482.

14. Manchikanti L, Boswell MV, Singh V, Benyamin RM, Fellows B, Abdi S, Buenaventura RM, Conn A, Datta S, Derby R, Falco FJE, Erhart S, Diwan S, Hayek SM, Helm S, Parr AT, Schultz DM, Smith HS, Wolfer LR, Hirsch JA. Comprehensive evidence-based guidelines for interventional techniques in the management of chronic spinal pain. Pain Physi- 
cian 2009; 12:699-802.

15. Manchikanti L, Boswell MV, Datta S, Fellows B, Abdi S, Singh V, Benyamin RM, Falco FJE, Helm S, Hayek S, Smith HS. Comprehensive review of therapeutic interventions in managing chronic spinal pain. Pain Physician 2009; 12:E123E198.

16. Manchikanti L, Schultz DM, Racz GB. Cervical transforaminal epidural injections. In: Manchikanti L, Singh V (eds). Interventional Techniques in Chronic Spinal Pain, ASIPP Publishing, Paducah, KY, 2007, pp 455-478.

17. Manchikanti L, Singh V, Derby R, Helm S, Trescot AM, Staats PS, Prager JP, Hirsch JA. Review of occupational medicine practice guidelines for interventional pain management and potential implications. Pain Physician 2008; 11:271-289.

18. Manchikanti L, Singh V, Helm S, Trescot AM, Hirsch JA. A critical appraisal of 2007 American College of Occupational and Environmental Medicine (ACO$E M)$ practice guidelines for interventional pain management: An independent review utilizing AGREE, AMA, IOM, and other criteria. Pain Physician 2008; 11:291-310.

19. Manchikanti L, Singh V, Derby R, Schultz DM, Benyamin RM, Prager JP, Hirsch JA. Reassessment of evidence synthesis of occupational medicine practice guidelines for interventional pain management. Pain Physician 2008; 11:393482.

20. Manchikanti L. Evidence-based medicine, systematic reviews, and guidelines in interventional pain management: Part 1: Introduction and general considerations. Pain Physician 2008, 11:161-186.

21. Manchikanti L, Hirsch JA, Smith HS. Evidence-based medicine, systematic reviews, and guidelines in interventional pain management: Part 2: Randomized controlled trials. Pain Physician 2008; 11:717-773.

22. Manchikanti L, Benyamin RM, Helm S, Hirsch JA. Evidence-based medicine, systematic reviews, and guidelines in interventional pain management: Part 3: Systematic reviews and meta-analysis of randomized trials. Pain Physician 2009; 12:35-72.

23. Manchikanti L, Singh V, Smith HS, Hirsch JA. Evidence-based medicine, systematic reviews, and guidelines in interventional pain management: Part
4: Observational studies. Pain Physician 2009; 12:73-108.

24. Manchikanti L, Datta S, Smith HS, Hirsch JA. Evidence-based medicine, systematic reviews, and guidelines in interventional pain management: Part 6. Systematic reviews and meta-analyses of observational studies. Pain Physician 2009; 12:819-850.

25. Conn A, Buenaventura R, Datta S, Abdi $S$, Diwan S. Systematic review of caudal epidural injections in the management of chronic low back pain. Pain Physician 2009; 12:109-135.

26. Parr AT, Diwan S, Abdi S. Lumbar interlaminar epidural injections in manag ing chronic low back and lower extremity pain: A systematic review. Pain Physician 2009; 12:163-188.

27. Buenaventura RM, Datta S, Abdi S, Smith HS. Systematic review of therapeutic lumbar transforaminal epidural steroid injections. Pain Physician 2009; 12:233-251.

28. Stav A, Ovadia L, Sternberg A, Kaadan M, Weksler N. Cervical epidural steroid injection for cervicobrachialgia. Acta Anaesthesiol Scand 1993; 37:562-566.

29. Castagnera L, Maurette P, Pointillart V, Vital JM, Erny P, Senegas J. Long term results of cervical epidural steroid injection with and without morphine in chronic cervical radicular pain. Pain 1994; 58:239-243.

30. Pasqualucci A, Varrassi G, Braschi A, Peduto VA, Brunelli A, Marinangeli $F$, Gori F, Colò F, Paladini A, Mojoli F. Epidural local anesthetic plus corticosteroid for the treatment of cervical brachial radicular pain: Single injection versus continuous infusion. Clin J Pain 2007; 23:551-557.

31. Byrod G, Otani K, Brisby H, Rydevik B, Olmarker K. Methylprednisolone reduces the early vascular permeability increase in spinal nerve roots induced by epidural nucleus pulposus application. J Orthop Res 2000; 18:983-987.

32. Hayashi N, Weinstein JN, Meller ST, Lee HM, Spratt KF, Gebhart GF. The effect of epidural injection of betamethasone or bupivacaine in a rat model of lumbar radiculopathy. Spine (Phila Pa 1976) 1998; 23:877-885.

33. Lee HM, Weinstein JN, Meller ST, Hayashi N, Spratt KF, Gebhart GF. The role of steroids and their effects on phospholipase A2: An animal model of radiculopathy. Spine (Phila Pa 1976)
1998; 23:1191-1196.

34. Minamide A, Tamaki T, Hashizume H, Yoshida M, Kawakami M, Hayashi N. Effects of steroids and lipopolysaccharide on spontaneous resorption of herniated intervertebral discs: An experimental study in the rabbit. Spine (Phila Pa 1976) 1998; 23:870-876.

35. Tachihara H, Sekiguchi M, Kikuchi S, Konno S. Do corticosteroids produce additional benefit in nerve root infiltration for lumbar disc herniation. Spine (Phila Pa 1976) 2008; 33:743-747.

36. Hua SY, Chen YZ. Membrane receptormediated electrophysiological effects of glucocorticoid on mammalian neurons. Endocrinology 1989; 124:687691.

37. Flower RJ, Blackwell GJ. Anti-inflammatory steroid induced biosynthesis of a phospholipase A2 inhibitor which prevents prostaglandin generation. Nature 1979; 278:456-459.

38. Lundin A, Magnuson A, Axelsson K, Nilsson O, Samuelsson L. Corticosteroids preoperatively diminishes damage to the C-fibers in microscopic lumbar disc surgery. Spine (Phila Pa 1976) 2005; 30:2362-2367.

39. Pasqualucci A. Experimental and clinical studies about the preemptive analgesia with local anesthetics. Possible reasons of the failure. Minerva Anestesiol 1998; 64:445-457.

40. Arner S, Lindblom U, Meyerson BA, Molander $\mathrm{C}$. Prolonged relief of neuralgia after regional anesthetic block. A call for further experimental and systematic clinical studies. Pain 1990; 43:287297.

41. Abram SE, Likavec MJ. Pain syndromes and rationale for management. Neurogenic pain. In Raj P (ed). Practical Management of Pain. Year Book Medical Publishers, Chicago, 1986, pp 182-191.

42. Sato C, Sakai A, Ikeda Y, Suzuki H, Sakamoto A. The prolonged analgesic effect of epidural ropivacaine in a rat model of neuropathic pain. Anesth Analg 2008; 106:313-320.

43. Wertheim HM, Rovenstine EA. Suprascapular nerve block. Anesthesiology 1941; 2:541.

44. Manchikanti L, Singh V, Falco FJ, Cash KA, Pampati V. Lumbar facet joint nerve blocks in managing chronic facet joint pain: One-year follow-up of a randomized, double-blind controlled trial: Clinical Trial NCTo0355914. Pain Physician 2008; 11:121-132. 
45. Manchikanti L, Singh V, Falco FJ, Cash KA, Fellows B. Cervical medial branch blocks for chronic cervical facet joint pain: A randomized double-blind, controlled trial with one-year follow-up. Spine (Phila Pa 1976) 2008; 33:18131820.

46. Manchikanti L, Singh V, Falco FJE, Cash KA, Pampati V. Effectiveness of thorac ic medial branch blocks in managing chronic pain: A preliminary report of a randomized, double-blind controlled trial: Clinical trial NCT00355706. Pain Physician 2008; 11:491-504.

47. Manchikanti L, Cash KA, McManus CD, Pampati V, Smith HS. Preliminary results of randomized, equivalence trial of fluoroscopic caudal epidural injections in managing chronic low back pain: Part 1. Discogenic pain without disc herniation or radiculitis. Pain Physician 2008; 11:785-800.

48. Manchikanti L, Singh V, Cash KA, Pampati V, Damron KS, Boswell MV. Preliminary results of randomized, equivalence trial of fluoroscopic caudal epidural injections in managing chronic low back pain: Part 2. Disc herniation and radiculitis. Pain Physician 2008; 11:801-815.

49. Manchikanti L, Singh V, Cash KA, Pampati V, Datta S. Preliminary results of randomized, equivalence trial of fluoroscopic caudal epidural injections in managing chronic low back pain: Part 3. Post surgery syndrome. Pain Physician 2008; 11:817-831.

50. Manchikanti L, Cash KA, McManus CD, Pampati V, Abdi S. Preliminary results of randomized, equivalence trial of fluoroscopic caudal epidural injections in managing chronic low back pain: Part 4. Spinal stenosis. Pain Physician 2008; 11:833-848.

51. Riew KD, Park JB, Cho YS, Gilula L, Patel A, Lente LG, Bridwell KH. Nerve root blocks in the treatment of lumbar radicular pain. A minimum five-year follow-up. J Bone Joint Surg Am 2006; 88:1722-1725.

52. Moher D, Schulz KF, Altman D, for the CONSORT Group. The CONSORT statement: Revised recommendations for improving the quality of reports of parallel-group randomized trials. JAMA 2001; 285:1987-1991.

53. Altman DG, Schulz KF, Moher D, Egger M, Davidoff F, Elbourne D, Gøtzsche PC, Lang T; CONSORT GROUP (Consolidated Standards of Reporting Trials). The revised CONSORT statement for re- porting randomized trials: Explanation and elaboration. Ann Intern Med 2001; 134:663-694.

54. Cleland JA, Childs JD, Whitman JM. Psychometric properties of the Neck Disability Index and Numeric Pain Rating Scale in patients with mechanical neck pain. Arch Phys Med Rehabil 2008; 89:69-74.

55. Pietrobon R, Coeytaux RR, Carey TS, Richardson WJ, DeVellis RF. Standard scales for measurement of functional outcome for cervical pain or dysfunction: a systematic review. Spine (Phila $\mathrm{Pa}$ 1976) 2002; 27:515-522.

56. Vernon H, Mior S. The Neck Disability Index: A study of reliability and validity. I Manipulative Physiol Ther 1991; 14:409-415.

57. Pereira J, Lawlor P, Vigano A, Dorgan M, Bruera E. Equianalgesic dose ratios for opioids. A critical review and proposals for long-term dosing. J Pain Symptom Manage 2001; 22:672-687. Narcotic analgesic converter, GlobalRPh Inc. www.globalrph.com/narcotic.cgi

58. Browner WS, Newman TB, Cummings SR, Hulley SB. Estimating sample size and power. In Hulley SB, Cummings SR, Browner WS, Grady D, Hearst N, Newman TB (eds). Designing Clinical Research: An Epidemiologic Approach, 2nd ed. Lippincott, Williams \& Wilkins, Philadelphia, 2001, pp 6584.

59. Koes BW, Scholten RJ, Mens JMA, Bouter LM. Epidural steroid injections for low back pain and sciatica. An updated systematic review of randomized clinical trials. Pain Digest 1999; 9:241-247.

6o. Abdi S, Datta S, Trescot AM, Schultz DM, Adlaka R, Atluri SL, Smith HS, Manchikanti L. Epidural steroids in the management of chronic spinal pain: A systematic review. Pain Physician 2007; 10:185-212.

61. Peloso PMJ, Gross A, Haines T, Trinh K, Goldsmith CH, Burnie SJ, Cervical Overview Group. Medicinal and injection therapies for mechanical neck disorders. Cochrane Database Syst Rev 2007; 3:CDooo319.

62. Manchikanti L, Falco FJE, Boswell MV, Hirsch JA. Facts, fallacies, and politics of comparative effectiveness research: Part I. Basic considerations. Pain Physician 2010; 13:E23-E54.

63. Manchikanti L, Falco FJE, Boswell MV, Hirsch JA. Facts, fallacies, and politics of comparative effectiveness research:
Part 2 - Implications for interventional pain management. Pain Physician 2010; 13:E55-E79.

64. Hotopf M, Churchill R, Lewis G. Pragmatic randomized controlled trials in psychiatry. $\mathrm{Br} /$ Psychiatry 1999; 175:217-223.

65. Tunis SR, Stryer DB, Clancy CM. Practical clinical trials. Increasing the value of clinical research for decision making in clinical and health policy. JAMA 2003; 290:1624-1632.

66. Roland M, Torgerson DJ. What are pragmatic trials? BMJ 1998; 316:285.

67. International Conference on Harmonisation of Technical Requirements for Registration of Pharmaceuticals for Human Use. ICH Harmonised Tripartite Guideline. Choice of Control Group and Related Issues in Clinical Trials E10. July 20, 2000.

68. Smuck M, Levin JH. RE: Manchikanti L, Singh V, Falco FJE, Cash KA, Fellows B. Cervical medial branch blocks for chronic cervical facet joint pain: A randomized double-blind, controlled trial with one-year follow-up. Spine (Phila Pa 1976) 2008; 33:1813-20. Spine (Phila $P A$ 1976) 2009; 34:1116-1117.

69. Manchikanti L, Singh V, Falco FJE. In response to Smuck M, Levin JH. RE: Manchikanti L, Singh V, Falco FJE, Cash KA, Fellows B. Cervical medial branch blocks for chronic cervical facet joint pain: A randomized double-blind, controlled trial with one-year follow-up. Spine (Phila Pa 1976) 2009; 34:11161117.

70. Pham Dang C, Lelong A, Guilley J, Nguyen JM, Volteau C, Venet G, Perrier C, Lejus C, Blanloeil Y. Effect on neurostimulation of injectates used for perineural space expansion before placement of a stimulating catheter: Normal saline versus dextrose $5 \%$ in water. Reg Anesth Pain Med 2009; 34:398-403.

71. Tsui BC, Kropelin B, Ganapathy S, Finucane B. Dextrose $5 \%$ in water: Fluid medium maintaining electrical stimulation of peripheral nerve during stimulating catheter placement. Acta Anaesthesiol Scand 2005; 49:1562-1565.

72. Indahl A, Kaigle AM, Reikeräs O, Holm $\mathrm{SH}$. Interaction between the porcine lumbar intervertebral disc, zygapophysial joints, and paraspinal muscles. Spine (Phila Pa 1976) 1997; 22:28342840.

73. Indahl A, Kaigle A, Reikerås 0 , Holm S. Electromyographic response of the 
porcine multifidus musculature after nerve stimulation. Spine (Phila $\mathrm{Pa}$ 1976) $1995 ; 20: 2652-2658$.

74. Manchikanti L. Pharmacology of neuraxial steroids. In Manchikanti L, Singh $\mathrm{V}$ (eds). Interventional Techniques in Chronic Spinal Pain, ASIPP Publishing, Paducah, KY, 2007, pp 167-184.

75. Mao J, Chen LL. Systemic lidocaine for neuropathic pain relief. Pain 2000; 87:7-17.

76. Ferrante FM, Paggioli J, Cherukuri S, Arthru GR. The analgesic response to intravenous lidocaine in the treatment of neuropathic pain. Anesth Analg 1996; 82:91-97.

77. Lavoie PA, Khazen T, Filion PR. Mechanisms of the inhibition of fast axonal transport by local anesthetics. Neuropharmacology 1989; 28:175-181.

78. Bisby MA. Inhibition of axonal transport in nerves chronically treated with local anesthetics. Exp Neurol 1975; 47:481-489.

79. Manchikanti L. Interventional pain management: Past, present, and future. The Prithvi Raj lecture: Presented at the 4 th World Congress-World Institute of Pain, Budapest, 2007. Pain Pract 2007; 7:357-371.

80. Kawakami M, Weinstein JN, Chatani K, Spratt KF, Meller ST, Gebhart GF. Experimental lumbar radiculopathy. Behavioral and histologic changes in a model of radicular pain after spinal nerve root irritation with chromic gut ligatures in the rat. Spine (Phila Pa 1976) 1994; 19:1795-1802.

81. Decosterd I, Woolf CJ. Spared nerve injury: An animal model of persistent pe- ripheral neuropathic pain. Pain 2000; 87:149-158.

82. Pennypacker KR, Hong JS, McMillian MK. Implications of prolonged expression of Fos-related antigens. Trends Pharmacol Sci 1995; 16:317-321.

83. Aoki Y, Rydevik B, Kikuchi S. Local application of disc-related cytokines on spinal nerve roots. Spine (Phila Pa 1976) 2002; 27:1614-1617.

84. Norimoto M, Ohtori S, Yamashita M, Inoue G, Yamauchi K, Koshi T, Suzuki M, Orita S, Eguchi Y, Sugiura A, Ochiai N, Takaso M, Takahashi K. Direct application of the TNF-alpha inhibitor, etanercept, does not affect CGRP expression and phenotypic change of DRG neurons following application of nucleus pulposus onto injured sciatic nerves in rats. Spine (Phila Pa 1976) 2008; 33:24032408.

85. Genevay S, Finckh A, Payer M, Mezin F, Tessitore E, Gabay C, Guerne PA. Elevated levels of tumor necrosis factoralpha in periradicular fat tissue in patients with radiculopathy from herniated disc. Spine (Phila Pa 1976) 2008; 33:2041-2046.

86. Sugiura A, Ohtori S, Yamashita M, Inoue G, Yamauchi K, Koshi T, Suzuki M, Norimoto M, Orita S, Eguchi Y, Takahashi Y, Watanabe TS, Ochiai N, Takaso M, Takahashi K. Existence of nerve growth factor receptors, tyrosine kinase $a$ and $p 75$ neurotrophin receptors in intervertebral discs and on dorsal root ganglion neurons innervating intervertebral discs in rats. Spine (Phila Pa 1976) 2008; 33:2047-2051.
87. Yamashita M, Ohtori S, Koshi T, Inoue G, Yamauchi K, Suzuki M, Takahashi K. Tumor necrosis factor-alpha in the nucleus pulposus mediates radicular pain, but not increase of inflammatory peptide, associated with nerve damage in mice. Spine (Phila Pa 1976) 2008; 33:1836-1842.

88. Igarashi T, Kikuchi S, Myers RR. Exogenous tumor necrosis factor-alpha mimics nucleus pulposus-induced neuropathology. Molecular, histologic, and behavioral comparisons in rats. Spine (Phila Pa 1976) 2000; 25:2975-2980.

89. McCarron RF, Wimpee MW, Hudkins PG, Laros GS. The inflammatory effect of nucleus pulposus: A possible element in the pathogenesis of low-back pain. Spine (Phila Pa 1976) 1987; 12:760764.

90. Olmarker K, Blomquist J, Stromberg J. Inflammatogenic properties of nucleus pulposus. Spine (Phila Pa 1976) 1995; 20:665-669.

91. Johansson A, Hao J, Sjolund B. Local corticosteroid application blocks transmission in normal nociceptive C-fibres. Acta Anaesthesiol Scand 1990; 34:335338.

92. Mackinnon SE, Hudson AR, Gentili F, Kline DG, Hunter D. Peripheral nerve injection injury with steroid agents. Plast Reconstr Surg 1982; 69:482-489.

93. Shishido H, Kikuchi S, Heckman H, Myers RR. Dexamethasone decreases blood flow in normal nerves and dorsal root ganglia. Spine (Phila Pa 1976) 2002; 27:581-586. 